Special Edition: An Update on Male Infertility: Factors, Mechanisms and Interventions

\title{
Do lifestyle practices impede male fertility?
}

\author{
Kristian Leisegang $^{1}$ (D) | Sulagna Dutta ${ }^{2}$ (i)
}

${ }^{1}$ School of Natural Medicine, University of the Western Cape, Cape Town, South Africa

${ }^{2}$ Department of Oral Biology and Biomedical Sciences, Faculty of Dentistry, MAHSA

University, Selangor, Malaysia

\section{Correspondence}

Kristian Leisegang, School of Natural Medicine, University of the Western Cape, Blanckenberg Rd, Bellville, Cape Town, South Africa.

Email: kleisegang@uwc.ac.za

\begin{abstract}
Alongside an increasing prevalence of couple and male infertility, evidence suggests there is a global declining trend in male fertility parameters over the past few decades. This may, at least in part, be explained through detrimental lifestyle practices and exposures. These include alcohol and tobacco consumption, use of recreational drugs (e.g., cannabis, opioids and anabolic steroids), poor nutritional habits, obesity and metabolic syndrome, genital heat stress (e.g., radiation exposure through cell phones and laptops, prolonged periods of sitting, tight-fitting underwear and recurrent hot baths or saunas), exposure to endocrine-disrupting chemicals (e.g., pesticide residue, bisphenol A, phthalates and dioxins) and psychological stress. This review discusses these lifestyle practices and the current evidence associated with male infertility. Furthermore, known mechanisms of action are also discussed for each of these. Common mechanisms associated with a reduction in spermatogenesis and/ or steroidogenesis due to unfavourable lifestyle practices include inflammation and oxidative stress locally or systemically. It is recommended that relevant lifestyle practices are investigated in clinical history of male infertility cases, particularly in unexplained or idiopathic male infertility. Appropriate modification of detrimental lifestyle practices is further suggested and recommended in the management of male infertility.
\end{abstract}

\section{KEYWORDS}

endocrine disruptors, genital heat stress, male infertility, nutrition and obesity, tobacco, alcohol and recreational drugs

\section{1 | BACKGROUND}

\subsection{Trends in male reproductive health}

Infertility is defined as the inability to achieve conception after 12 months of regular ( $>3$ times per week) sexual intercourse without contraception (WHO, 2010). Approximately $15 \%$ of couples globally are infertile, with up to half of these due to male factor infertility. Male infertility is considered the primary cause of infertility in $20 \%$ of couples and a contributory factor in $30 \%-40 \%$ of cases (Esteves, Hamada, Kondray, Pitchika, \& Agarwal, 2012; Hamada, Esteves, \& Agarwal, 2011; Hamada, Singh, \& Agarwal, 2011). The prevalence of male infertility in the general population is reportedly up to $15 \%$
(Barratt et al., 2017). In 1992, Carlsen, Giwercman, Keiding, and Skakkebæk (1992) reported a decline in semen quality over the past 50 years, which may reflect a general decline in male fertility. Although this decline in semen quality remains controversial, this has been supported by numerous subsequent studies (Aitken, 2013; Carlsen et al., 1992; Jørgensen et al., 2001; Levine et al., 2017; Sengupta, 2015; Sengupta, Dutta, \& Krajewska-Kulak, 2017; Sengupta, Dutta, Tusimin, İrez, \& Krajewska-Kulak, 2018; Swan, Elkin, \& Fenster, 2000). Potential explanations and confounding factors for this data include genetic and epigenetic inheritance, intrauterine and lifestyle exposures (Gaskins, Colaci, Mendiola, Swan, \& Chavarro, 2012). Furthermore, of clinical importance, male infertility may be a predictor of increased all-cause morbidity and mortality 
in males, more specifically cardiovascular, metabolic, oncological and autoimmune diseases. This may be due to common underlying mechanisms likely also mediated through similar genetic, epigenetic, developmental and lifestyle factors (Choy \& Eisenberg, 2018).

Results of male infertility trends analysis in the literature over 20 years (1998-2017) have reported that testicular cancer and obesity/metabolic syndrome have received the most significant amount of scientific interest, followed by investigation into azoospermia, hypogonadism and then lifestyle factors or occupational exposures (Baskaran, Agarwal, Leisegang, et al., 2019; Baskaran, Agarwal, Panner Selvam, et al., 2019). Although causes and risk factors of male infertility are numerous, the impact of lifestyle on male fertility outcomes is receiving increased interest. Furthermore, sperm DNA fragmentation and seminal oxidative stress are receiving increasing attention as a cause/mechanism of male infertility (Baskaran, Agarwal, Leisegang, et al., 2019; Baskaran, Agarwal, Panner Selvam, et al., 2019). With increased research focus on the impact of lifestyle in male infertility, as well as common mechanisms of oxidative stress and DNA fragmentation, there is increasing actionable evidence emerging for clinicians to better manage males of infertile couples (Hayden, Flannigan, \& Schlegel, 2018).

\subsection{Overview of medical and nonmedical causes of male infertility}

The causes of male infertility are broad, including genetic disease, polygenetic risk factors, environmental exposures, geographical aspects and well-defined reproductive and systemic pathology (Esteves et al., 2012; ; Palani, Sengupta, Agarwal, \& Henkel, 2020). Genetic and developmental causes include Klinefelter syndrome and Kallmann syndrome ( 1.2\%) and cryptorchidism ( 2.7\% cases). Acquired disorders include varicocele $( \pm 25 \%$ cases), reproductive tract obstruction ( 15\%), male accessory gland infections ( 10\% cases), antisperm antibodies ( 10\%), hypogonadism ( $1.5 \%$ cases), testicular failure ( 1.1\% cases), urogenital complications (e.g., obstruction following infections or inflammation, including mumps orchitis) and sexual or ejaculation dysfunction ( $0.7 \%-2 \%$ cases) (Esteves et al., 2012; Hamada et al., 2011, 2011).

Approximately $25 \%$ of male infertility cases are considered of unknown origin, divided into unexplained or idiopathic (Jung \& Seo, 2014; Sabanegh \& Agarwal, 2012). Unexplained male infertility (UMI) is defined as normal sperm parameters on two or more occasions with normal endocrine and physical evaluation and the absence of female factor infertility (Jung \& Seo, 2014; Sabanegh \& Agarwal, 2012). Idiopathic male infertility (IMI) is defined as a reduction in one or more semen parameters in males who are otherwise normal on endocrine and physical assessment (Jung \& Seo, 2014; Sabanegh \& Agarwal, 2012). Recently, the concept of male oxidative stress infertility (MOSI) has been proposed to define a significant subset of men diagnosed with IMI (Agarwal et al., 2019).

\section{Key points}

- General decline in sperm parameters may be confounded by changes in lifestyle practices

- Poor nutrition, tobacco smoking and chronic or heavy alcohol consumption, causes of genital heat stress, radiation exposure and psychological stress have evidence to suggest a negative impact on male fertility

- Oxidative stress and inflammation are common underlying mediators of infertility in many lifestyle practices

- Males should be investigated for lifestyle practices that may impede fertility, particularly in unexplained and idiopathic infertility

- Favourable modification of lifestyle practices may improve fertility outcomes in males

\section{Potential areas of research}

- Though multiple lifestyle factors are known to impact male fertility, there is no male infertility risk score based on one's lifestyle practices

- What are the mechanisms by which poor lifestyle practices affect male reproductive system?

- To what extent cessation of harmful lifestyle practices can lead to improved male fertility?

Exposure to numerous environmental agents and lifestyle factors negatively affects male reproduction (Figure 1 ). This includes smoking and alcohol use, recreational drugs (such as cannabis, cocaine, opioids and anabolic steroids), poor nutritional intake, obesity, increased testicular heat (e.g., prolonged sitting or radiation), exposure to endocrine-disrupting chemicals and psychological stress (Durairajanayagam, 2018; Esteves et al., 2012; Leisegang \& Dutta, 2019). Within the context of decreasing semen quality and the investigation into seminal oxidative stress and sperm DNA fragmentation, these lifestyle practices and the evidence available on the impact on male reproduction are discussed in this review.

\section{2 | LIFESTYLE PRACTICES/FACTORS LINKED TO MALE INFERTILITY}

\subsection{Alcohol consumption}

The consumption of acute or moderate ( $<5$ units per week) alcohol appears to have minimal effect on sperm parameters, except reduced semen volume, and may increase testosterone and improve assisted reproductive technique (ART) outcomes (Jensen et al., 2014; Sermondade et al., 2012). However, chronic and heavy (>20-25 units per week) consumption of alcohol negatively affects spermatogenesis and semen parameters, including sperm concentration, motility and morphology (Li, Lin, Li, \& Cao, 2011; 
reported to have normozoospermia compared with $37 \%$ of nonalcoholic men (Gaur et al., 2010). It is reported that spermatogenic arrest and Sertoli cell-only syndrome are common alcohol-induced testicular disorders (Pajarinen \& Karhunen, 1994). Increased
Muthusami \& Chinnaswamy, 2005) (Jensen et al., 2014; Karmon et al., 2017) (Table 1). Chronic alcohol abuse is associated with oligozoospermia, asthenozoospermia and teratozoospermia (Gaur, Talekar, \& Pathak, 2010), with only $12 \%$ of chronic alcoholic males

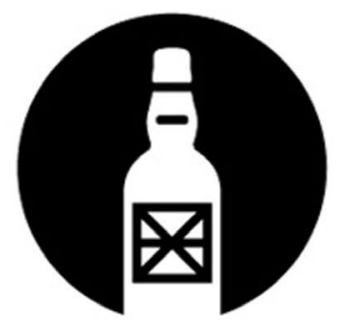

Alcohol

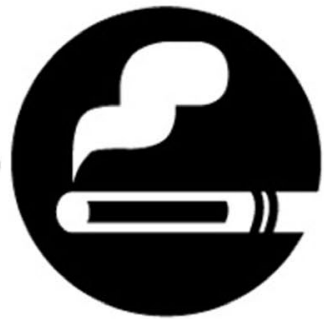

Tobacco
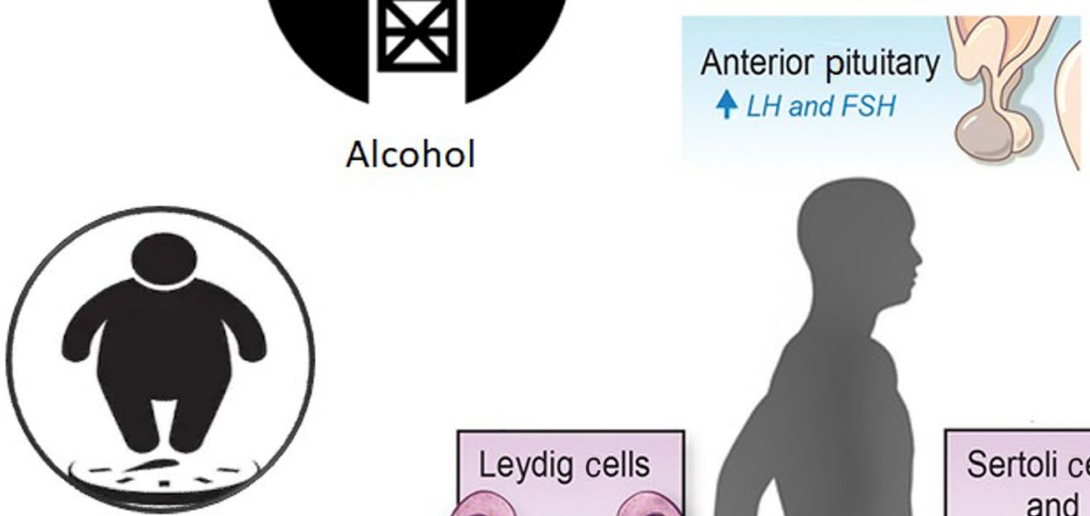

Obesity

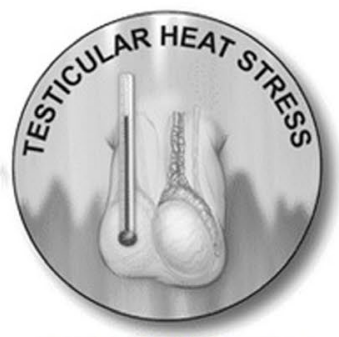

Heat exposure

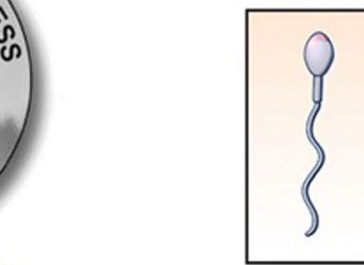

Testosterone
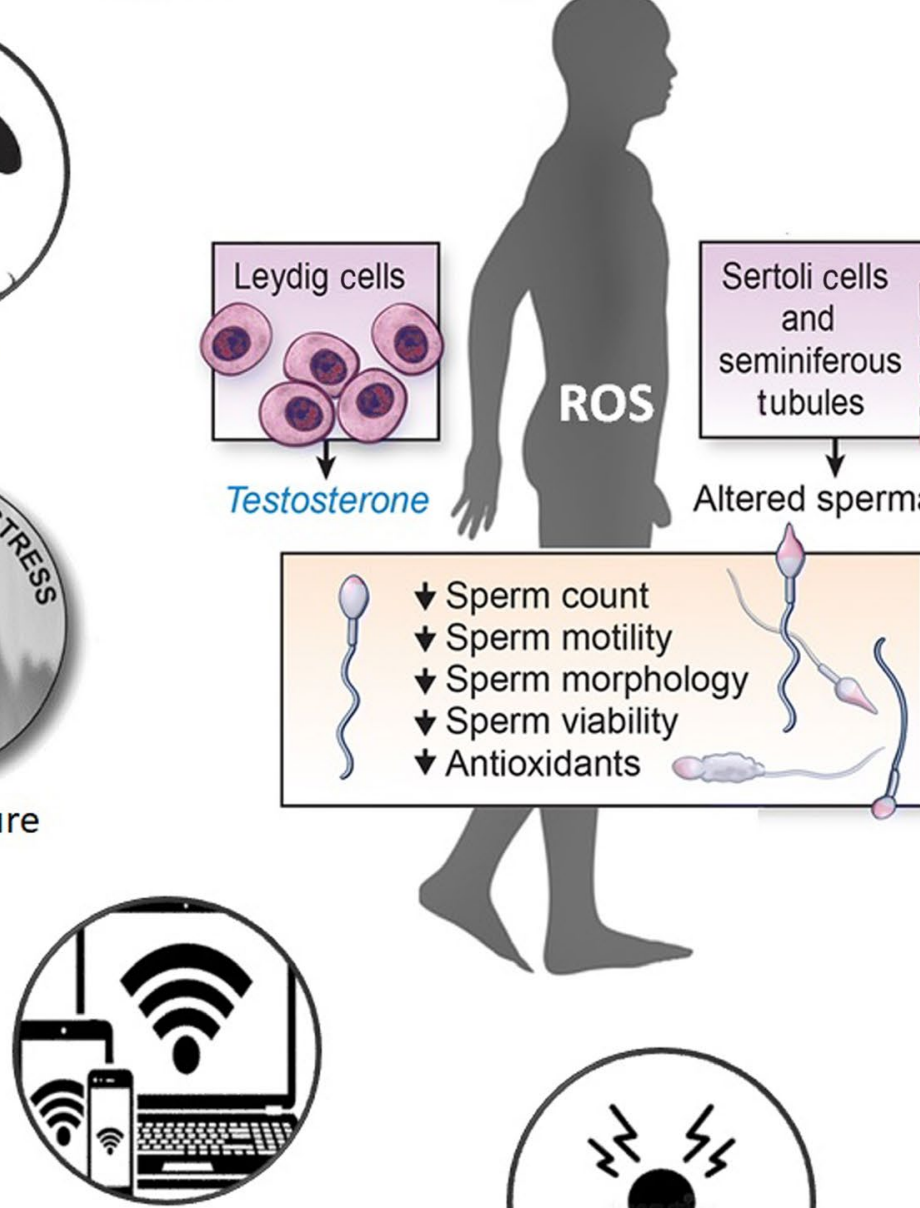

Radiation 1

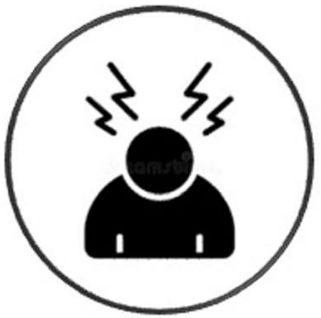

Psychological

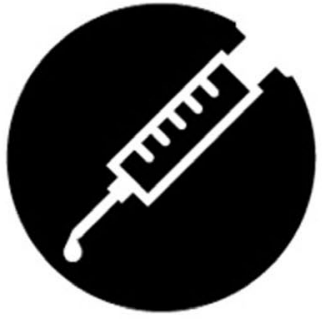

Recreational drugs

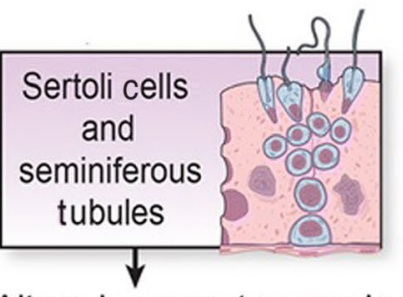

Altered spermatogenesis 
seminal leucocytes have also been reported with chronic alcohol use (Close, Roberts, \& Berger, 1990). Reproductive endocrine changes of chronic alcohol use include reduced testosterone and progesterone alongside increased LH, FSH and prolactin, although this is not consistent in the literature (Jensen et al., 2014). Impairment of steroidogenesis and testosterone metabolism is suggested to be mediated in part through a reduction in Leydig cell numbers and testicular atrophy (Li et al., 2011).

Animal studies in mice and rats have further contributed to understanding the impact of ethanol on the reproductive system. Chronic exposure to ethanol induces oxidative stress with an increase in enzymatic antioxidants, leading to a long-term imbalance in the oxidant/antioxidant ratio. This is correlated with chromatin decondensation, DNA fragmentation and apoptosis (Aboulmaouahib et al., 2018; Rahimipour, Talebi, Anvari, Sarcheshmeh, \& Omidi, 2013). Apoptosis is mediated through upregulation of the Fas system, increased activation of p53, caspases and cytochrome c translocation. Increased apoptosis is also reported in Sertoli cells, associated germ cells and Leydig cells alongside spermatozoa (Jana, Jana, De, \& Guha, 2010). Chronic alcohol intake is further correlated with epigenetic modulations and the transfer of these modifications to the next generation, which is emerging as an important contributor to alcohol-related foetal growth defects via modified paternal DNA methylation (Chang et al., 2017).

\section{2 | Tobacco}

Approximately $21 \%$ of males of reproductive age smoke tobacco regularly in the United States (Penzias et al., 2018), having a detrimental effect on fertility and fecundity (Penzias et al., 2018). Smoking exposes males to over 4,700 potentially mutagenic compounds, particularly to polycyclic aromatic hydrocarbons amongst other toxic chemicals (Borgerding \& Klus, 2005). However, the impact on male reproduction remains generally underappreciated (Penzias et al., 2018). Oligozoospermia, asthenozoospermia and teratozoospermia are common findings in moderate and heavy tobacco users (Gaur et al., 2010). More than 15 cigarettes per day in male partners have been reported to reduce fecundity in couples attempting to conceive (Hassan \& Killick, 2004), and this is proportional to the number of cigarettes per day and duration of smoking (Harlev, Agarwal, Gunes, Shetty, \& Plessis, 2015).

Negative effects of smoking on sperm parameters include reduced sperm concentration, motility and vitality, increased abnormal morphology, seminal leucocyte concentration and DNA fragmentation, alongside reduced capacitation and acrosome reactions (Dai, Wang, \& Qiao, 2015; Penzias et al., 2018; Sharma, Harlev, Agarwal, \& Esteves, 2016). By altering the physiological epigenetic regulation, paternal smoking increases the risk of genetic disease, malformation and cancer in the progeny (Calogero et al., 2009).

Smoking induces oxidative stress in the testes, affecting spermatogenesis and steroidogenesis (Zalata, Ahmed, Allamaneni, Comhaire, \& Agarwal, 2004). This leads to impaired chromatin condensation,
DNA integrity, oocyte binding, as well as epigenetic modifications transmitted to the next generation (Sharma, Biedenharn, Fedor, \& Agarwal, 2013; Sharma et al., 2016). Additional mechanisms include hypoxia, altered energy regulation in spermatozoa through the impairment of creatine kinase activity, reduced testosterone synthesis in Leydig cells and increased metabolism of testosterone in the liver (Dai et al., 2015; Ghaffari \& Rostami, 2013).

\section{3 | Use of recreational drugs}

The consumption of numerous recreational drugs such as cannabis, opioid narcotics, cocaine, other methamphetamines and anabolicandrogenic steroids may have a negative impact on male fertility. These drugs induce hypogonadism through impairment of the hypothalamic-pituitary-testicular axis (HPT) (Du Plessis, Cabler, McAlister, Sabanegh, \& Agarwal, 2010; de Souza \& Hallak, 2011).

Cannabis is the most widely used recreational illicit substance, with up to $2.5 \%$ of the global adult population using cannabis, predominantly males of reproductive age ( $20 \%$ of males aged $26-34$ years, and $\sim 11 \%$ aged 35-49 years) (Fronczak, Kim, \& Barqawi, 2012). Cannabis modulates human biology and reproduction predominantly via the endogenous endocannabinoid system (ECS), mediated through the activity of lipophilic endogenous cannabinoids (arachidonoylglycerol ether, virodhamine, $\mathrm{N}$-arachidonoylethanolamine and 2-arachidonoylglycerol) which act through the cannabinoid (CB) receptors CB1 and CB2. These receptors have been isolated in the testes, prostate and seminal vesicles, including germ cells, spermatids, mature spermatozoa, Sertoli cells and Leydig cells (Du Plessis, Agarwal, \& Syriac, 2015). The ECS can be modulated through cannabis consumption, particularly through exposure to the exogenous cannabinoids delta-9 tetrahydrocannibinol (THC) and cannabidiol (CBD) as the most well-known and studied of the more than 130 cannabinoids currently identified in Cannabis spp. (Di Marzo \& Piscitelli, 2015). Consumption of cannabis may reduce LH and testosterone with acute ( $<10$ joints per week) and chronic use ( $>10$ joints per week) (Du Plessis et al., 2015). THC inhibits LH synthesis and release from the anterior pituitary, resulting in dose-dependent hypogonadism that may induce clinical presentations including erectile dysfunction, reduced libido, ejaculatory dysfunction and ejaculatory dysfunction (Barazani, Katz, Nagler, \& Stember, 2014). This hypogonadism leads to abnormal spermatogenesis, negatively affecting sperm parameters including concentration, motility, morphology, viability and increased seminal leucocyte concentration, alongside impaired capacitation, hyperactivity, acrosome reaction and hemizona binding (Close et al., 1990; Du Plessis et al., 2015). Approximately 33\% of chronic male users of cannabis present with oligozoospermia (Fronczak et al., 2012). Chronic administration of THC in animal models impairs mitotic and meiotic stages of spermatogenesis, resulting in abnormal morphological forms (Fronczak et al., 2012). Cannabis use can further induce epigenetic changes that can be transferred to the next generation (Du Plessis et al., 2015). However, further studies in humans are required to fully understand the physiological function of the ECS in male reproduction and the potential modulation via cannabinoids. 
Use of nonprescription opioids is reportedly the second highest illicit drug used. This includes $8.3 \%$ and $4.8 \%$ of males aged 26-34 years and 35-49 years, respectively (Fronczak et al., 2012). An illicit abuse of narcotics has increased significantly to epidemic proportions, particularly in the USA with over 33,000 deaths reported annually and representing a significant public health concern (Soelberg, Brown, Vivier, Meyer, \& Ramachandran, 2017). Opioid narcotics reportedly reduce LH through the activation of the negative feedback pathways to the hypothalamus and anterior pituitary, resulting in hypogonadotropic hypogonadism that is further correlated with reduced oestrogen (Daniell, 2002).

Anabolic steroids are estimated to be used by $3 \%-4 \%$ of men during their lifetime (Barazani et al., 2014; Close et al., 1990), especially as performance-enhancing drugs in competitive sports, and increasingly in amateur sports and for recreational use (Nieschlag \& Vorona, 2015). These exogenous steroids inhibit spermatogenesis through inhibition of the HPT axis via negative feedback on pituitary $\mathrm{LH}$ and $\mathrm{FSH}$ and steroidogenesis, further causing a reduction of intratesticular testosterone concentration (Close et al., 1990). Steroids further cause end-stage spermatogenesis arrest and subsequent oligozoospermia or azoospermia, altered sperm morphology and testicular atrophy (Close et al., 1990). With long-term use, loss of libido, erectile dysfunction and gynaecomastia are also reported (Nieschlag \& Vorona, 2015).

\section{4 | Caffeine consumption}

Intake of caffeine (1,3,7-trimethylxanthine) is very common globally. Caffeine is found in a variety of natural substances, including coffee, tea, chocolate and cola-containing soft drinks as well as energy drinks (Jensen, Swan, Skakkebæk, Rasmussen, \& Jørgensen, 2010). The impact of caffeine intake on human reproduction remains inconclusive. Some studies have found no significant effect of caffeine consumption on male fertility parameters, or weak evidence for higher consumption (Karmon et al., 2017). More than 6 cups of coffee per day has been suggested to reduce fecundity in couples (Hassan \& Killick, 2004). However, Oluwole, Salami, Ogunwole, and Raji (2016) concluded that moderate ( $300 \mathrm{mg} /$ day) consumption of caffeine is safe (Oluwole et al., 2016).

Caffeine is suggested to negatively impact fertility through DNA defects associated with aneuploidy and DNA breaks, although epidemiological data remain inconclusive and controversial (Ricci et al., 2017). This seemed most significant for caffeine consumed through sugar-rich cola soft drinks compared with coffee and tea consumption (Ricci et al., 2017). Further evidence suggests $>3$ cups of coffee per day in males may increase sperm DNA damage by $20 \%$ (Schmid et al., 2006). Jensen et al. (2010) reported a caffeine intake of $>800 \mathrm{mg} /$ day reduced sperm concentration and total sperm count, although this was not statistically significant.

Consumption of 4-7 cups of coffee per day in adult males has been suggested to increase testosterone concentrations, approximately $14 \%$ higher than men with low intake of caffeine (Ramlau-Hansen, Thulstrup, Bonde, Olsen, \& Bech, 2008). Interestingly, sons of mothers consuming 4-7 cups of coffee per day had lower testosterone concentrations compared to those with lower coffee consumption (Ramlau-Hansen et al., 2008). Caffeine has also been associated with lower levels of oestrogen in offspring, which is suggested to affect Sertoli cell maturation in foetal life (Ramlau-Hansen et al., 2008). Caffeine exposure in peripubertal rats decreases testosterone production and delays the onset of maturation, with a subsequent decrease in seminiferous tubule diameter and epithelial cell height (Bae, Choi, Choi, \& Roh, 2016). Park, Choi, Choi, Yim, and Roh (2015) found similar outcomes in peripubertal rats through prenatal caffeine exposure. In adult rats, caffeine exposure resulted in decreased body weight, and relative decreased weight in epididymis, prostate and seminal vesicles, with reduced sperm count and viability. This was also associated with increased testosterone and decreased $\mathrm{LH}$ and FSH levels (Oluwole et al., 2016). However, increased caffeine consumption has also been controversially associated with increased sperm motility (Marshburn, Sloan, \& Hammond, 1989). Caffeine is also a known modulator of cellular metabolism (Dias et al., 2015), and through inhibition of intracellular CAMP, there is an upregulation of cellular metabolism and ATP production for motility (Marshburn et al., 1989).

\section{5 | Obesity}

Clinically defined as a body mass index (BMI) $>30 \mathrm{~kg} / \mathrm{m}^{2}$, obesity is characterised by the accumulation of excessive visceral adipose tissue leading to various complication including cardiovascular disease (CVD), type 2 diabetes mellitus, numerous malignancies, neurodegeneration and accelerated ageing (McPherson \& Lane, 2015). Obesity has significantly increased in recent decades globally, which is observed alongside a global decline in male fertility parameters (Hammoud, Gibson, Peterson, Meikle, \& Carrell, 2008). Although the underlying pathophysiology is complex and poorly understood, mechanisms include low-grade chronic systemic inflammation, oxidative stress, hyperinsulinaemia, hyperleptinaemia and, in males, hypogonadotropic hypogonadism and hyperoestrogenaemia (Leisegang, Henkel, \& Agarwal, 2019; Esteves, 2019). An increase in seminal insulin and leptin as well as reduced seminal parameters has also been reported in obese males (Leisegang, Bouic, Menkveld, \& Henkel, 2014).

The relationship between obesity and male infertility has been widely investigated, with over 14,000 articles investigating the impact of obesity and metabolic syndrome on male infertility (Baskaran, Agarwal, Leisegang, et al., 2019; Baskaran, Agarwal, Panner Selvam, et al., 2019). Although there are studies with inconclusive and negative associations (Du Plessis et al., 2010), obesity is generally accepted to impair the male fertility potential, including poor semen quality, hypogonadism and increased testicular heat (Bandel et al., 2015; Du Plessis et al., 2010; Hammoud et al., 2008; MacDonald, Herbison, Showell, \& Farquhar, 2009; Palmer, Bakos, 
Fullston, \& Lane, 2012). Paternal obesity is also correlated with increased pregnancy complications, reduced live birth rates, reduced success of ART and epigenetic transfer to the offspring through modified sperm RNA levels, DNA methylation, protamination and histone acetylation (Davidson, Millar, Jones, Fatum, \& Coward, 2015; Palmer et al., 2012). Metabolic syndrome, which importantly may include metabolic risk independent of obesity, has also been reported to reduce male fertility parameters (Leisegang, Bouic, \& Henkel, 2016).

Animal models report an inflammatory cytokine influx and increased cytokine expression in testicular cells (Salas-Huetos, Bulló, \& Salas-Salvadó, 2017). Obesity-induced testicular inflammation negatively affects spermatogenesis and steroidogenesis, impairs epididymal sperm maturation, increases DNA fragmentation and induces epigenetic modification (Yildirim et al., 2019). Altered gene expression of antioxidant defences reported includes superoxide dismutase (SOD), glutathione peroxidase (GPx) and Nrf2 (Palmer et al., 2012). Obesity-induced alterations in testicular histology include reduced seminiferous tubule diameters, reduced germ cell numbers, epithelial cell atrophy, reduced Johnson scores, reduced adhesions between Sertoli cells and spermatogenic cells and disruption of the blood-testes barrier through alterations in the expression of tight junction proteins (Demirci \& Sahin, 2019; Yang et al., 2018). However, further studies are required to understand the mediators of obesity-induced male infertility (Almabhouh,
Aziz, Durairajanayagam, \& Singh, 2020; Almabhouh, Md Mokhtar, et al., 2020; Leisegang et al., 2019), and to identify appropriate management options and advice for patients, including nutritional and lifestyle changes, supplementation (antioxidants and micronutrients), and prescription or surgical options to improve fertility outcomes.

\section{6 | Diet}

Although there are many confounding factors, increasing evidence suggests nutrition has an independent role in semen quality and male reproductive potential (Gaskins et al., 2012). Modern 'Westernised' diets are characterised by energy-dense, refined and nutritionally poor foods, including high-energy sugars, trans-fatty and hydrolysed fatty acids, omega- 6 polyunsaturated fatty acids and processed foods, alongside reduced intake of fruits and vegetables, omega-3 polyunsaturated fatty acids, important micronutrients, antioxidants and phyto-compounds (Eslamian et al., 2016). This dietary pattern may lead to reduced total sperm count, sperm concentration, progressive motility and normal morphology (Eslamian et al., 2016), with an increased risk for astheno-, oligo- and teratozoospermia (Oostingh, Steegers-Theunissen, Vries, Laven, \& Koster, 2017). However, other studies have not reported these associations (Vujkovic et al., 2009).

TAB LE 1 Potential negative impact of various lifestyle factors on male reproductive semen and endocrine parameters in the male reproductive system

\begin{tabular}{|c|c|c|c|}
\hline $\begin{array}{l}\text { Lifestyle } \\
\text { Factor }\end{array}$ & Semen Parameters & $\begin{array}{l}\text { Endocrine } \\
\text { Parameters }\end{array}$ & $\begin{array}{l}\text { Proposed } \\
\text { Mechanisms }\end{array}$ \\
\hline $\begin{array}{c}\text { Alcohol } \\
\text { Consumption }\end{array}$ & $\begin{array}{l}\text { Seminal } \\
\text { leukocytes } \\
\text { SDF } \\
\text { Concentration } \\
\text { Motility } \\
\text { Viability } \\
\text { Morphology }\end{array}$ & 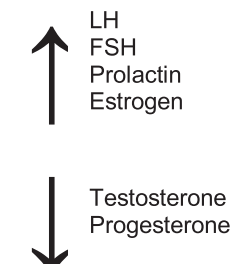 & $\begin{array}{l}\text { - Impaired } \\
\text { spermatogenesis and } \\
\text { steroidogenesis } \\
\text { - Spermatogenic arrest } \\
\text { - Impaired Leydig cell } \\
\text { - Apoptosis } \\
\text { - Testicular atrophy and } \\
\text { OS }\end{array}$ \\
\hline $\begin{array}{l}\text { Tobacco } \\
\text { Consumption }\end{array}$ & $\begin{array}{l}\text { Seminal } \\
\text { leukocytes } \\
\text { SDF } \\
\text { Concentration } \\
\text { Motility } \\
\text { Viability } \\
\text { Morphology }\end{array}$ & Testosterone & $\begin{array}{ll}\text { - Impaired } & \text { spermatogenesis and } \\
\text { steroidogenesis } \\
\text { - Testicular OS } \\
\text { - Hypoxia }\end{array}$ \\
\hline $\begin{array}{c}\text { Cannabis, } \\
\text { Opioids and } \\
\text { Anabolic Steroids }\end{array}$ & $\begin{array}{l}\text { Concentration } \\
\text { Motility } \\
\text { Sperm functions }\end{array}$ & $\begin{array}{l}\text { LH } \\
\text { Testosterone }\end{array}$ & $\begin{array}{l}\text { - Impaired HPT axis and } \\
\text { spermatogenesis }\end{array}$ \\
\hline Caffeine & $\begin{array}{ll}\text { - } & \text { No significant impact } \\
\text { confirmed } \\
\text { - } \\
\text { May increase sperm } \\
\text { motility } \\
\text { - May increase SDF } \\
\end{array}$ & $\begin{array}{ll}\text { - } & \text { May increase } \\
\text { testosterone } \\
\text { - } \\
\text { May decrease LH } \\
\text { and FSH }\end{array}$ & Not determined \\
\hline
\end{tabular}

FSH, follicle-stimulating hormone; HPT axis, hypothalamic-pituitary-testicular axis; LH, luteinising hormone; OS, oxidative stress; SDF, sperm DNA fragmentation. 
Foods strongly suggested to impair male fertility include high-energy sugar (including sweets and beverages), potatoes, saturated and trans-fatty acids, red meat, processed meat, dairy (including skimmed milk and cheese), soy products, alongside increased caffeine and alcohol consumption. Sweet consumption increases the risk for asthenozoospermia, potentially mediated through increased insulin resistance and oxidative stress (Oostingh et al., 2017). Refined sugars, such as sweets and high carbohydrate diets, are associated with reduced sperm concentration and impaired motility (Attaman et al., 2012). Consumption of red meat, rich in saturated fatty acids, has been associated with impaired semen parameters (Giahi, Mohammadmoradi, Javidan, \& Sadeghi, 2015) and the impairment of sperm count and motility in a dose-dependent manner (Gaskins et al., 2012; Jensen et al., 2012; Mendiola et al., 2009). Increased dairy intake is also associated with oligoasthenozoospermia and asthenozoospermia, although a recommended threshold has not been determined (Oostingh et al., 2017). Reduced intake of fruits and vegetables, fibre, polyunsaturated fatty acids (particularly omega-3 fatty acids) and foods rich in micronutrients, antioxidants and phytochemicals (particularly vitamin $\mathrm{C}$ and $\mathrm{E}$, $\beta$-carotine, zinc, selenium, L-carnitine and lycopene) increases the risk of poor semen quality (Giahi et al., 2015).

Unfavourable nutritional intake correlates with increased testicular and seminal oxidative stress and associated sperm DNA fragmentation and impaired chromatin condensation. Epigenetic modulation has been reported, with transmission to the offspring. However, direct causality has not been demonstrated, although this is associated with increased risk of metabolic disorders, obesity and cancer in the offspring (Siddeek, Mauduit, Simeoni, \& Benahmed, 2018; Soubry, 2015; Vujkovic et al., 2009).

\section{7 | Occupational and environmental factors}

\subsection{1 | Excessive heat exposure}

The process of spermatogenesis is temperature sensitive, with optimum temperature of about $2^{\circ} \mathrm{C}$ lower than body temperature (Durairajanayagam, Agarwal, \& Ong, 2015). An increase in scrotal temperature leads to genital heat stress (GHS), impairing spermatogenesis (Durairajanayagam et al., 2015). Occupational hazards, such as high workplace temperature (e.g., glass, foundry and steel industries, kitchens, bakeries and mines), may impose risk of heat stress and GHS on the workers (Epstein \& Moran, 2006). GHS negatively correlates with semen quality and is considered a major contributor in male infertility (Durairajanayagam et al., 2015; Hamerezaee et al., 2018).

Currently, reports suggest that long hours of sitting posture, high mean ambient day time temperatures, regular long-distance driving, habit of regular hot baths, very tight underwear and intensive cycling may evoke infertility problems via GHS (Durairajanayagam, 2018). In addition, genital insulation while sleeping, excessive hot occupational environment (e.g., bakers and welders), placing laptop or electrical gadgets on the lap for long hours, heated car seats or floor and frequent sauna sessions are possible mediators of male infertility through GHS. The clinical disorders owing to high scrotal temperature and GHS include cryptorchidism, varicocele and acute/chronic febrile illnesses (Durairajanayagam, Sharma, Plessis, $\&$ Agarwal, 2014).

The mechanism of GHS-induced spermatogenic impairments includes induction of oxidative stress with high reactive oxygen species (ROS) concentration and reduced antioxidants in the genital tract and ejaculate, sperm chromatin disintegration, DNA fragmentation, sperm mitochondrial dysfunction and increased rate of germ cell apoptosis (Durairajanayagam et al., 2015, 2014). Spermatozoa may be most susceptible to damage in the pre-meiotic stage at which chromatin remains mostly unstable due to the ongoing processes of histone modifications and hyperacetylation. This unstable chromatin may get easily affected by increased genital heat and hinder sperm chromatin condensation (Mima, Greenwald, \& Ohlander, 2018).

\subsection{2 | Endocrine disruptors}

Endocrine disruptors (EDs) refer to chemicals which at effective dosage interfere with hormonal regulations of physiological functions in utero, in children or in adults. In male reproduction, EDs mainly include the hormone oestrogen and its derivatives, as well as agonists and antagonists of oestrogen or androgen receptors (Manikkam, Tracey, Guerrero-Bosagna, \& Skinner, 2013). Essential environmental factors linked with male infertility comprise various synthetic and natural EDs. These include common environmental pollutants such as bisphenol A (BPA), phthalates, dioxins, toxic metals and pesticides (e.g., bipyridyl herbicide, organochlorine and organophosphates) (Sharma et al., 2013). Exposure to EDs is mediated mostly via maternal transfer during foetal development, and via dietary sources (Manikkam et al., 2013). The dietary sources of EDs are particularly through dairy, meat and soy items (Skakkebæk, Meyts, \& Main, 2001).

Environmental EDs, particularly pesticides, have deleterious impact upon semen quality as they may impair steroidogenesis (Chiu et al., 2016). Intake of fruits and vegetables that contain less pesticide contamination has been shown to correlate with higher semen quality as compared to those with more pesticide contamination (Chiu et al., 2016). Pesticides such as the bipyridyl herbicides, organophosphates and organochlorine affect spermatogenesis by induction of oxidative stress. The EDs such as bisphenol A (BPA), dioxins and phthalates also operates via the similar pathway (Sharma et al., 2013). Moreover, in utero exposure to EDs seems to alter male gonadal development. It has been suggested that male reproductive disorders, including reduced sperm count, positively correlate with a high risk of testicular cancer and cryptorchidism (Skakkebæk et al., 2001). Gestational exposure to oestrogen or its derivatives has been reported to cause sperm epigenetic changes (Manikkam et al., 2013). 


\subsection{3 | lonising radiation}

Ionising radiation (IR) has rapidly become very common in clinical practice over the recent few decades. The reason behind this is mostly the usage of radiographic testing and radiotherapy for cancer treatment. As the testes are placed in the specialised structure of a scrotal sack below the abdominal cavity, they are more susceptible to radiation-induced damage (Abuelhija, Weng, Shetty, \& Meistrich, 2013). Human testes are highly sensitive, and thereby following a radiotherapy, they show limited capability to revive its normal spermatogenesis. This is because radiation leads to arrest of spermatogonial stem cells at the stage of differentiation (Meistrich \& Samuels, 1985). This arrest may be caused by several factors, such as the diagnostic time, pre-treatment semen parameters, as well as the dose and exposure duration (Gandini et al., 2006). These conditions require counselling of the patients for spermatozoa cryopreservation and concepts of assisted reproduction, prior to treatment.

Solar ultraviolet radiation (UVR) also has deleterious effects over living organisms (Häder et al., 1998). In recent decades, occupational and environmental exposures to low wavelength UVR have increased by many folds (Krutmann, Morita, \& Chung, 2012). Specifically, ultraviolet $B(U V B)$ has been suggested to induce molecular and cellular level disruptions, including conformational changes of essential enzymes as well as the nucleic acids (Dahms \& Lee, 2010). UVB affects sperm functions particularly by disrupting the membrane semi-permeability. This in turn leads to an influx of ROS and induction of intracellular oxidative stress. High ROS concentration causes intracellular damage, most prominently sperm DNA fragmentation (Krutmann et al., 2012), thereby impairing sperm functions (Heck, Vetrano, Mariano, \& Laskin, 2003).

\subsection{4 | Nonionising radiation}

Nonionising radiation can affect the body through radiofrequency (RF) sources, such as WiFi, cell phones, bluetooth, induction heaters, high-frequency dielectric instruments, broadcast antennas and pulsed radars of high power. Reports suggest that RF exposure may lead to deteriorated semen quality through reduction in semen volume, sperm concentration, sperm viability and motility (Deepinder, Makker, \& Agarwal, 2007).

Both the thermal and nonthermal effects of RF on male fertility have been reported. Since temperature regulation of the testes mainly depends on surface conduction rather than blood flow, EMW energy is more absorbed by the testes than any other organs, thereby increasing testicular temperature and GHS, affecting spermatogenesis (Wallach, Kandeel, \& Swerdloff, 1988). The nonthermal effects of RF include induction of oxidative stress and alterations of cell membrane potentials, which impairs germ cell proliferation and stimulates apoptosis (Hamada et al., 2011, 2011). It may also cause sperm DNA fragmentation and epigenetic changes, degeneration of Leydig cells and reduced level of testosterone, and thus impaired maintenance of spermatogenesis (Hamada et al., 2011, 2011).

\section{8 | Psychological stress}

Psychological stress may be caused by different interpersonal, social and environmental factors. It is one on the main contributors to idiopathic male infertility and reportedly associated with impaired semen parameters (Gollenberg et al., 2010). Stress potentially increases the levels of cortisol, epinephrine and norepinephrine (Flaherty et al., 2017) and induces intracellular ROS that leads to disruption of cellular microstructures (Dutta, Henkel, Sengupta, \& Agarwal, 2020) and onset of inflammatory responses (Flaherty et al., 2017). Stressinduced alterations in glucocorticoid actions on Leydig cells include the suppression of androgen synthesis and induction of apoptosis (Hardy et al., 2005; Ikeda et al., 1999; Maneesh \& Jayalekshmi, 2006). $11 \beta$-Hydroxysteroid dehydrogenase (11ßHSD)-mediated glucocorticoid synthesis inhibits the activities of the steroidogenic enzyme and thus impairs steroidogenesis in the Leydig cells (MacAdams, White, $\&$ Chipps, 1986). This may reduce testosterone levels without altering the LH levels, whereas in chronic stress, reduction in the levels of both gonadotropins and GnRH has been suggested (Wagenmaker, Breen, Oakley, Tilbrook, \& Karsch, 2009). Active coping with stress using an assertive or confrontational attitude in men may adversely affect testicular functions. This is mediated through stimulation of the adrenergic system, testicular vasoconstriction, reduced testosterone production and thus impaired spermatogenesis (Pook, Tuschen-Caffier, Kubek, Schill, \& Krause, 2005).

\section{3 | ROLE OF LIFESTYLE MANAGEMENT IN IMPROVING MALE REPRODUCTIVE HEALTH}

A summary of modifiable lifestyle factors that may improve male fertility outcomes is provided in Table 2. Clinical evidence suggests improved semen parameters in males with reduced adiposity through diet and exercise, even in the absence of reduced BMI, improving sperm concentration, motility, morphology and DNA fragmentation (Faure et al., 2014; Håkonsen et al., 2011; Mir, Franken, Andrabi, Ashraf, \& Rao, 2018). Animal models suggest weight loss improves embryo quality, development and metabolic function in the offspring of obese fathers (McPherson \& Lane, 2015). Furthermore, the adherence to the Mediterranean, or similar, dietary patterns is associated with improved semen quality. This includes diets rich in fruits, vegetables, fibre, seafood, nuts, seeds and vegetable oils, and including antioxidant-rich plant-based foods (Gaskins et al., 2012; Karayiannis et al., 2017). Micronutrients particularly beneficial to male fertility include carotenes, ascorbic acid, tocopherols, selenium zinc, L-arginine and co-enzyme Q10 (Giahi et al., 2015). Regular moderate exercise may improve fertility parameters in men, which also improves oxidative stress and DNA fragmentation. However, 
TABLE 2 Modifiable lifestyle factors in the prevention and management of male infertility

\begin{tabular}{|c|c|}
\hline Modifiable lifestyle factor & Corrective measures \\
\hline Nutrition & $\begin{array}{l}\text { - High intake of plant-based food such as fruits and vegetables, } \\
\text { fibre and antioxidant-rich foods, nuts, seeds, fish and other } \\
\text { seafood } \\
\text { - Limited intake of high-energy sugar and processed foods and } \\
\text { drink, red meat, processed meat, full-fat dairy and soy-based } \\
\text { foods }\end{array}$ \\
\hline $\begin{array}{l}\text { Tobacco, alcohol and } \\
\text { caffeine consumption }\end{array}$ & $\begin{array}{l}\text { - Complete cessation of tobacco use } \\
\text { - Cessation or light ( } 1 \text { unit per day) consumption of alcohol } \\
\text { - Moderate caffeine consumption ( } 1 \text { - } 3 \text { cups of coffee or } \\
\text { equivalent) }\end{array}$ \\
\hline Weight management & $\begin{array}{l}\text { - Reduce excessive adiposity } \\
\text { - Appropriate nutritional intake (Mediterranean diet or similar) } \\
\text { and exercise } \\
\text { - Improve micronutrient deficiencies }\end{array}$ \\
\hline Stress management & $\begin{array}{l}\text { - Behavioural cognitive therapy } \\
\text { - Mind-body practice such as meditation and yoga } \\
\text { - Manage stress related to sexual performance or outcome }\end{array}$ \\
\hline $\begin{array}{l}\text { Avoidance of other } \\
\text { lifestyle exposures }\end{array}$ & $\begin{array}{l}\text { - Genital heat stress (e.g., hot baths and saunas, tight-fitting } \\
\text { underwear, prolonged sitting, intensive cycling) } \\
\text { - Radiation (e.g., cell phones and laptops near groin) } \\
\text { - Endocrine-disrupting chemicals (e.g., nonorganic produce and } \\
\text { plastics) } \\
\text { - Recreational drugs: cannabis; opioids; anabolic steroids }\end{array}$ \\
\hline
\end{tabular}

intensive and vigorous exercise should be avoided (Du Plessis, Kashou, Vaamonde, \& Agarwal, 2011).

Complete cessation of tobacco is important to improve altered sperm parameters (Dai et al., 2015), where smoking cessation has been associated with improved semen parameters (Harte \& Meston, 2012; Oyeyipo, Raji, Emikpe, \& Bolarinwa, 2011). Limited ( $<5$ units per week) alcohol consumption may be a safe lifestyle practice, although moderate and heavy (>25 units per weeks) alcohol consumption should be avoided (Gaur et al., 2010; Sansone et al., 2018; Nathalie Sermondade et al., 2010). Caffeine intake should be moderated to three cups of coffee or the equivalent caffeine per day (Jensen et al., 2010). Evidence strongly suggests that cannabis use should be avoided for male infertility management (Du Plessis et al., 2015). The negative impact of anabolic steroids on male the HPT suppression may include gonadotropins, selective estrogen receptor modulators and aromatase inhibitors, although the off-label use is poorly studied (McBride \& Coward, 2016).

Psychological stress management through mind-body practice, meditation and yoga has been reported to improve male fecundity (Bhongade et al., 2015; Yao \& Mills, 2016). Further research is required to investigate the effects of stress release techniques and therapeutic approaches such as cognitive behavioural therapy and mindfulness (Bhongade et al., 2015; Yao \& Mills, 2016). It is also important to consider and manage psychological stress relevant to sexual performance and fertility outcomes (Zorn, Auger, Velikonja, Kolbezen, \& Meden-Vrtovec, 2008). Adequate sleep also seems to be an important factor, which may improve semen quality (Alvarenga, Hirotsu, Mazaro-Costa, Tufik, \& Andersen, 2015; Viganò et al., 2017). However, thresholds for numerous lifestyle parameters have not yet been determined and require further investigation.

\section{4 | CONCLUSION}

Poor lifestyle factors are significant determinants of health outcomes, and in recent years, these are increasingly associated with negative impacts on male reproduction. Alcohol and tobacco consumption, metabolic disorders, poor nutrition, sedentary lifestyle, occupational, therapeutic or environmental exposures to excessive heat, excessive physical labour, EDs, radiation and psychological stress are some of the contributing factors to male infertility. Oxidative stress serves as a common mechanism through which these causatives act to impair male reproductive functions. Recording of clinical history relevant to poor lifestyle practices is important in the clinical assessment of male infertility. Appropriate modification of identified lifestyle practices that may impede male infertility is recommended in clinical practice.

\section{ORCID}

Kristian Leisegang (iD https://orcid.org/0000-0002-3003-8048

Sulagna Dutta iD https://orcid.org/0000-0002-7893-5282

\section{REFERENCES}

Aboulmaouahib, S., Madkour, A., Kaarouch, I., Sefrioui, O., Saadani, B., Copin, H., ... Cadi, R. (2018). Impact of alcohol and cigarette smoking consumption in male fertility potential: Looks at lipid peroxidation, enzymatic antioxidant activities and sperm DNA damage. Andrologia, 50(3), e12926.

Abuelhija, M., Weng, C. C., Shetty, G., \& Meistrich, M. L. (2013). Rat models of post-irradiation recovery of spermatogenesis: Interstrain differences. Andrology, 1(2), 206-215.

Agarwal, A., Parekh, N., Selvam, P., Kumar, M., Henkel, R., Shah, R., Tremellen, K. (2019). Male Oxidative Stress Infertility (MOSI): Proposed terminology and clinical practice guidelines for 
management of idiopathic male infertility. The World Journal of Men's Health, 37, 296.

Aitken, R. J. (2013). Falling sperm counts twenty years on: Where are we now? Asian Journal of Andrology, 15(2), 204.

Almabhouh, F., Aziz, N. A. A. A., Durairajanayagam, D., \& Singh, H. J. (2020). Could leptin be responsible for the reproductive dysfunction in obese men? Reproductive Biology, 20, 106-110. https://doi. org/10.1016/j.repbio.2020.01.003

Almabhouh, F. A., Md Mokhtar, A. H., Malik, I. A., Aziz, N. A. A. A., Durairajanayagam, D., \& Singh, H. J. (2020). Leptin and reproductive dysfunction in obese men. Andrologia, 52(1), e13433.

Alvarenga, T. A., Hirotsu, C., Mazaro-Costa, R., Tufik, S., \& Andersen, M. L. (2015). Impairment of male reproductive function after sleep deprivation. Fertility and Sterility, 103(5), 1355-1362.e1351.

Attaman, J. A., Toth, T. L., Furtado, J., Campos, H., Hauser, R., \& Chavarro, J. E. (2012). Dietary fat and semen quality among men attending a fertility clinic. Human Reproduction, 27(5), 1466-1474.

Bae, J., Choi, H., Choi, Y., \& Roh, J. (2016). Dose-and time-related effects of caffeine on the testis in immature male rats. Experimental Animals, 66, 29-39.

Bandel, I., Bungum, M., Richtoff, J., Malm, J., Axelsson, J., Pedersen, H. S., ... Giwercman, A. (2015). No association between body mass index and sperm DNA integrity. Human Reproduction, 30(7), 1704-1713.

Barazani, Y., Katz, B. F., Nagler, H. M., \& Stember, D. S. (2014). Lifestyle, environment, and male reproductive health. Urologic Clinics, 41(1), 55-66.

Barratt, C. L. R., Björndahl, L., De Jonge, C. J., Lamb, D. J., Osorio Martini, F., McLachlan, R., ... Tournaye, H. (2017). The diagnosis of male infertility: An analysis of the evidence to support the development of global WHO guidance-Challenges and future research opportunities. Human Reproduction Update, 23(6), 660-680.

Baskaran, S., Agarwal, A., Leisegang, K., Peter, N. P., Selvam, M. K. P., \& Henkel, R. (2019). An in-depth bibliometric analysis and current perspective on male infertility research. The World Journal of Men's Health, https://doi.org/10.5534/wjmh.180114. [Epub ahead of print].

Baskaran, S., Agarwal, A., Panner Selvam, M. K., Finelli, R., Robert, K. A., lovine, C., ... Henkel, R. (2019). Tracking research trends and hotspots in sperm DNA fragmentation testing for the evaluation of male infertility: A scientometric analysis. Reproductive Biology and Endocrinology, 17(1), 1-13

Bhongade, M., Prasad, S., Jiloha, R., Ray, P., Mohapatra, S., \& Koner, B. (2015). Effect of psychological stress on fertility hormones and seminal quality in male partners of infertile couples. Andrologia, 47(3), 336-342.

Borgerding, M., \& Klus, H. (2005). Analysis of complex mixtures-cigarette smoke. Experimental and Toxicologic Pathology, 57, 43-73.

Calogero, A., Polosa, R., Perdichizzi, A., Guarino, F., Vignera, S. L., Scarfia, A., ... Vicari, E. (2009). Cigarette smoke extract immobilizes human spermatozoa and induces sperm apoptosis. Reproductive Biomedicine Online, 19(4), 564-571.

Carlsen, E., Giwercman, A., Keiding, N., \& Skakkebæk, N. E. (1992). Evidence for decreasing quality of semen during past 50 years. British Mediacl Journal, 305(6854), 609-613.

Chang, R. C., Skiles, W. M., Chronister, S. S., Wang, H., Sutton, G. I., Bedi, Y. S., ... Golding, M. C. (2017). DNA methylation-independent growth restriction and altered developmental programming in a mouse model of preconception male alcohol exposure. Epigenetics, 12(10), 841-853.

Chiu, Y.-H., Gaskins, A. J., Williams, P. L., Mendiola, J., Jørgensen, N., Levine, H., ... Chavarro, J. E. (2016). Intake of fruits and vegetables with low-to-moderate pesticide residues is positively associated with semen-quality parameters among young healthy men-3. The Journal of Nutrition, 146(5), 1084-1092.
Choy, J. T., \& Eisenberg, M. L. (2018). Male infertility as a window to health. Fertility and Sterility, 110(5), 810-814.

Close, C. E., Roberts, P. L., \& Berger, R. E. (1990). Cigarettes, alcohol and marijuana are related to pyospermia in infertile men. The Journal of Urology, 144(4), 900-903.

Dahms, H.-U., \& Lee, J.-S. (2010). UV radiation in marine ectotherms: Molecular effects and responses. Aquatic Toxicology, 97(1), 3-14.

Dai, J.-B., Wang, Z.-X., \& Qiao, Z.-D. (2015). The hazardous effects of tobacco smoking on male fertility. Asian Journal of Andrology, 17(6), 954.

Daniell, H. W. (2002). Hypogonadism in men consuming sustained-action oral opioids. The Journal of Pain, 3(5), 377-384.

Davidson, L. M., Millar, K., Jones, C., Fatum, M., \& Coward, K. (2015). Deleterious effects of obesity upon the hormonal and molecular mechanisms controlling spermatogenesis and male fertility. Human Fertility, 18(3), 184-193.

de Souza, G. L., \& Hallak, J. (2011). Anabolic steroids and male infertility: A comprehensive review. BJU International, 108(11), 1860-1865.

Deepinder, F., Makker, K., \& Agarwal, A. (2007). Cell phones and male infertility: Dissecting the relationship. Reproductive Biomedicine Online, 15(3), 266-270.

Demirci, T., \& Sahin, E. (2019). The effect of chronic stress and obesity on sperm quality and testis histology in male rats; a morphometric and immunohistochemical study. Histology and Histopathology, 34(3), 287-302.

Di Marzo, V., \& Piscitelli, F. (2015). The endocannabinoid system and its modulation by phytocannabinoids. Neurotherapeutics: the Journal of the American Society for Experimental NeuroTherapeutics, 12(4), 692-698.

Dias, T. R., Alves, M. G., Bernardino, R. L., Martins, A. D., Moreira, A. C., Silva, J., ... Oliveira, P. F. (2015). Dose-dependent effects of caffeine in human Sertoli cells metabolism and oxidative profile: Relevance for male fertility. Toxicology, 328, 12-20.

Du Plessis, S. S., Agarwal, A., \& Syriac, A. (2015). Marijuana, phytocannabinoids, the endocannabinoid system, and male fertility. Journal of Assisted Reproduction and Genetics, 32(11), 1575-1588.

Du Plessis, S. S., Cabler, S., McAlister, D. A., Sabanegh, E., \& Agarwal, A. (2010). The effect of obesity on sperm disorders and male infertility. Nature Reviews Urology, 7(3), 153.

Du Plessis, S. S., Kashou, A., Vaamonde, D., \& Agarwal, A. (2011). Is there a link between exercise and male factor infertility. The Open Reproductive Science Journal, 3, 105-113.

Durairajanayagam, D. (2018). Lifestyle causes of male infertility. Arab Journal of Urology, 16(1), 10-20.

Durairajanayagam, D., Agarwal, A., \& Ong, C. (2015). Causes, effects and molecular mechanisms of testicular heat stress. Reproductive Biomedicine Online, 30(1), 14-27.

Durairajanayagam, D., Sharma, R. K., du Plessis, S. S., \& Agarwal, A. (2014). Testicular heat stress and sperm quality. In Male infertility (pp. 105-125). Berlin, Gemany: Springer Science+Business Media.

Dutta, S., Henkel, R., Sengupta, P., \& Agarwal, A. (2020). Physiological role of ROS in sperm function. In S. J. Parekattil, S. C. Esteves, \& A. Agarwal (Eds.), Male infertility: Contemporary clinical approaches, Andrology, ART and antioxidants, Vol. 2 (pp. 337-345). Cham, Switzerland: Springer.

Epstein, Y., \& Moran, D. S. (2006). Thermal comfort and the heat stress indices. Industrial Health, 44(3), 388-398.

Eslamian, G., Amirjannati, N., Rashidkhani, B., Sadeghi, M.-R., Baghestani, A.-R., \& Hekmatdoost, A. (2016). Adherence to the Western pattern is potentially an unfavorable indicator of asthenozoospermia risk: $\mathrm{A}$ case-control study. Journal of the American College of Nutrition, 35(1), $50-58$.

Esteves, S. C. (2019). Interventions to prevent sperm DNA damage effects on reproduction. In Genetic damage in human spermatozoa (pp. 119-148). Berlin, Gemany: Springer Science+Business Media.

Esteves, S. C., Hamada, A., Kondray, V., Pitchika, A., \& Agarwal, A. (2012). What every gynecologist should know about male 
infertility: An update. Archives of Gynecology and Obstetrics, 286(1), 217-229.

Faure, C., Dupont, C., Baraibar, M. A., Ladouce, R., Cedrin-Durnerin, I., Wolf, J. P., \& Lévy, R. (2014). In subfertile couple, abdominal fat loss in men is associated with improvement of sperm quality and pregnancy: A case-series. PLoS ONE, 9(2), e86300.

Flaherty, R. L., Owen, M., Fagan-Murphy, A., Intabli, H., Healy, D., Patel, A., ... Flint, M. S. (2017). Glucocorticoids induce production of reactive oxygen species/reactive nitrogen species and DNA damage through an iNOS mediated pathway in breast cancer. Breast Cancer Research, 19(1), 35.

Fronczak, C. M., Kim, E. D., \& Barqawi, A. B. (2012). The insults of illicit drug use on male fertility. Journal of Andrology, 33(4), 515-528.

Gandini, L., Sgrò, P., Lombardo, F., Paoli, D., Culasso, F., Toselli, L., ... Lenzi, A. (2006). Effect of chemo-or radiotherapy on sperm parameters of testicular cancer patients. Human Reproduction, 21(11), 2882-2889.

Gaskins, A. J., Colaci, D. S., Mendiola, J., Swan, S. H., \& Chavarro, J. E. (2012). Dietary patterns and semen quality in young men. Human Reproduction, 27(10), 2899-2907.

Gaur, D. S., Talekar, M. S., \& Pathak, V. P. (2010). Alcohol intake and cigarette smoking: Impact of two major lifestyle factors on male fertility. Indian Journal of Pathology and Microbiology, 53(1), 35.

Ghaffari, M. A., \& Rostami, M. (2013). The effect of cigarette smoking on human sperm creatine kinase activity: As an ATP buffering system in sperm. International Journal of Fertility \& Sterility, 6(4), 258.

Giahi, L., Mohammadmoradi, S., Javidan, A., \& Sadeghi, M. R. (2015). Nutritional modifications in male infertility: A systematic review covering 2 decades. Nutrition Reviews, 74(2), 118-130.

Gollenberg, A. L., Liu, F., Brazil, C., Drobnis, E. Z., Guzick, D., Overstreet, J. W., ... Swan, S. H. (2010). Semen quality in fertile men in relation to psychosocial stress. Fertility and Sterility, 93(4), 1104-1111.

Häder, D.-P., Lebert, M., Figueroa, F. L., Jiménez, C., Viñegla, B., \& PerezRodriguez, E. (1998). Photoinhibition in Mediterranean macroalgae by solar radiation measured on site by PAM fluorescence. Aquatic Botany, 61(3), 225-236.

Håkonsen, L. B., Thulstrup, A. M., Aggerholm, A. S., Olsen, J., Bonde, J. P., Andersen, C. Y., ... Ramlau-Hansen, C. H. (2011). Does weight loss improve semen quality and reproductive hormones? Results from a cohort of severely obese men. Reproductive Health, 8(1), 24.

Hamada, A., Esteves, S. C., \& Agarwal, A. (2011). The role of contemporary andrology in unraveling the mystery of unexplained male infertility. The Open Reproductive Science Journal, 4, 27-41.

Hamada, A. J., Singh, A., \& Agarwal, A. (2011). Cell phones and their impact on male fertility: Fact or fiction. The Open Reproductive Science Journal, 5(4), 125-137.

Hamerezaee, M., Dehghan, S. F., Golbabaei, F., Fathi, A., Barzegar, L., \& Heidarnejad, N. (2018). Assessment of semen quality among workers exposed to heat stress: A cross-sectional study in a steel industry. Safety and Health at Work, 9(2), 232-235.

Hammoud, A. O., Gibson, M., Peterson, C. M., Meikle, A. W., \& Carrell, D. T. (2008). Impact of male obesity on infertility: A critical review of the current literature. Fertility and Sterility, 90(4), 897-904.

Hardy, M. P., Gao, H.-B., Dong, Q., Ge, R., Wang, Q., Chai, W. R., ... Sottas, C. (2005). Stress hormone and male reproductive function. Cell and Tissue Research, 322(1), 147-153.

Harlev, A., Agarwal, A., Gunes, S. O., Shetty, A., \& du Plessis, S. S. (2015). Smoking and male infertility: An evidence-based review. The World Journal of Men's Health, 33(3), 143-160.

Harte, C. B., \& Meston, C. M. (2012). Association between smoking cessation and sexual health in men. BJU International, 109(6), 888-896.

Hassan, M. A., \& Killick, S. R. (2004). Negative lifestyle is associated with a significant reduction in fecundity. Fertility and Sterility, 81(2), 384-392.

Hayden, R. P., Flannigan, R., \& Schlegel, P. N. (2018). The role of lifestyle in male infertility: Diet, physical activity, and body habitus. Current Urology Reports, 19(7), 56.
Heck, D. E., Vetrano, A. M., Mariano, T. M., \& Laskin, J. D. (2003). UVB light stimulates production of reactive oxygen species: Unexpected role for catalase. Journal of Biological Chemistry, 278(25), 22432-22436.

Ikeda, M., Kodama, H., Fukuda, J., Shimizu, Y., Murata, M., Kumagai, J., \& Tanaka, T. (1999). Role of radical oxygen species in rat testicular germ cell apoptosis induced by heat stress. Biology of Reproduction, 61(2), 393-399.

Jana, K., Jana, N., De, D. K., \& Guha, S. K. (2010). Ethanol induces mouse spermatogenic cell apoptosis in vivo through over-expression of Fas/Fas-L, p53, and caspase-3 along with cytochrome $\mathrm{c}$ translocation and glutathione depletion. Molecular Reproduction and Development, 77(9), 820-833.

Jensen, T. K., Heitmann, B. L., Jensen, M. B., Halldorsson, T. I., Andersson, A.-M., Skakkebæk, N. E., ... Jørgensen, N. (2012). High dietary intake of saturated fat is associated with reduced semen quality among 701 young Danish men from the general population. The American Journal of Clinical Nutrition, 97(2), 411-418.

Jensen, T. K., Swan, S., Jørgensen, N., Toppari, J., Redmon, B., Punab, M., ... Andersson, A.-M. (2014). Alcohol and male reproductive health: A cross-sectional study of 8344 healthy men from Europe and the USA. Human Reproduction, 29(8), 1801-1809.

Jensen, T. K., Swan, S. H., Skakkebæk, N. E., Rasmussen, S., \& Jørgensen, N. (2010). Caffeine intake and semen quality in a population of 2,554 young Danish men. American Journal of Epidemiology, 171(8), 883-891.

Jørgensen, N., Andersen, A.-G., Eustache, F., Irvine, D. S., Suominen, J., Petersen, J. H., ... Skakkebæk, N. E. (2001). Regional differences in semen quality in Europe. Human Reproduction, 16(5), 1012-1019.

Jung, J. H., \& Seo, J. T. (2014). Empirical medical therapy in idiopathic male infertility: Promise or panacea? Clinical and Experimental Reproductive Medicine, 41(3), 108-114.

Karayiannis, D., Kontogianni, M. D., Mendorou, C., Douka, L., Mastrominas, M., \& Yiannakouris, N. (2017). Association between adherence to the Mediterranean diet and semen quality parameters in male partners of couples attempting fertility. Human Reproduction, 32(1), 215-222.

Karmon, A. E., Toth, T., Chiu, Y. H., Gaskins, A., Tanrikut, C., Wright, D., ... Team, E. S. (2017). Male caffeine and alcohol intake in relation to semen parameters and in vitro fertilization outcomes among fertility patients. Andrology, 5(2), 354-361.

Krutmann, J., Morita, A., \& Chung, J. H. (2012). Sun exposure: What molecular photodermatology tells us about its good and bad sides. Journal of Investigative Dermatology, 132(3), 976-984.

Leisegang, K., Bouic, P. J., \& Henkel, R. R. (2016). Metabolic syndrome is associated with increased seminal inflammatory cytokines and reproductive dysfunction in a case-controlled male cohort. American Journal of Reproductive Immunology, 76(2), 155-163.

Leisegang, K., Bouic, P. J., Menkveld, R., \& Henkel, R. R. (2014). Obesity is associated with increased seminal insulin and leptin alongside reduced fertility parameters in a controlled male cohort. Reproductive Biology and Endocrinology, 12(1), 34.

Leisegang, K., \& Dutta, S. (2019). Lifestyle management approaches to male infertility. In B. Rizk, A. Agarwal, \& E. S. Sabanegh Jr (Ed.), Male infertility in reproductive medicine: Diagnosis and management (pp. 11). Boca Raton, FL: CRC Press, Tayor \& Francis.

Leisegang, K., Henkel, R., \& Agarwal, A. (2019). Obesity and metabolic syndrome associated with systemic inflammation and the impact on the male reproductive system. American Journal of Reproductive Immunology, 82(5), e13178. https://doi.org/10.1111/aji.13178

Levine, H., Jørgensen, N., Martino-Andrade, A., Mendiola, J., WekslerDerri, D., Mindlis, I., ... Swan, S. H. (2017). Temporal trends in sperm count: A systematic review and meta-regression analysis. Human Reproduction Update, 23(6), 646-659.

Li, Y., Lin, H., Li, Y., \& Cao, J. (2011). Association between socio-psycho-behavioral factors and male semen quality: Systematic review and meta-analyses. Fertility and Sterility, 95(1), 116-123. 
MacADAMS, M. R., White, R. H., \& Chipps, B. E. (1986). Reduction of serum testosterone levels during chronic glucocorticoid therapy. Annals of Internal Medicine, 104(5), 648-651.

MacDonald, A., Herbison, G., Showell, M., \& Farquhar, C. (2009). The impact of body mass index on semen parameters and reproductive hormones in human males: A systematic review with meta-analysis. Human Reproduction Update, 16(3), 293-311.

Maneesh, M., \& Jayalekshmi, H. (2006). Role of reactive oxygen species and antioxidants on pathophysiology of male reproduction. Indian Journal of Clinical Biochemistry, 21(2), 80-89.

Manikkam, M., Tracey, R., Guerrero-Bosagna, C., \& Skinner, M. K. (2013). Plastics derived endocrine disruptors (BPA, DEHP and DBP) induce epigenetic transgenerational inheritance of obesity, reproductive disease and sperm epimutations. PLOS ONE, 8(1), e55387.

Marshburn, P. B., Sloan, C. S., \& Hammond, M. G. (1989). Semen quality and association with coffee drinking, cigarette smoking, and ethanol consumption. Fertility and Sterility, 52(1), 162-165.

McBride, J. A., \& Coward, R. M. (2016). Recovery of spermatogenesis following testosterone replacement therapy or anabolic-androgenic steroid use. Asian Journal of Andrology, 18(3), 373.

McPherson, N. O., \& Lane, M. (2015). Male obesity and subfertility, is it really about increased adiposity? Asian Journal of Andrology, 17(3), 450.

Meistrich, M. L., \& Samuels, R. C. (1985). Reduction in sperm levels after testicular irradiation of the mouse: A comparison with man. Radiation Research, 102(1), 138-147.

Mendiola, J., Torres-Cantero, A. M., Moreno-Grau, J. M., Ten, J., Roca, M., Moreno-Grau, S., \& Bernabeu, R. (2009). Food intake and its relationship with semen quality: A case-control study. Fertility and Sterility, 91(3), 812-818.

Mima, M., Greenwald, D., \& Ohlander, S. (2018). Environmental toxins and male fertility. Current Urology Reports, 19(7), 50.

Mir, J., Franken, D., Andrabi, S., Ashraf, M., \& Rao, K. (2018). Impact of weight loss on sperm DNA integrity in obese men. Andrologia, 50(4), e12957.

Muthusami, K., \& Chinnaswamy, P. (2005). Effect of chronic alcoholism on male fertility hormones and semen quality. Fertility and Sterility, 84(4), 919-924.

Nieschlag, E., \& Vorona, E. (2015). MECHANISMS IN ENDOCRINOLOGY: Medical consequences of doping with anabolic androgenic steroids: Effects on reproductive functions. European Journal of Endocrinology, 173(2), R47-R58.

Oluwole, O. F., Salami, S. A., Ogunwole, E., \& Raji, Y. (2016). Implication of caffeine consumption and recovery on the reproductive functions of adult male Wistar rats. Journal of Basic and Clinical Physiology and Pharmacology, 27(5), 483-491.

Oostingh, E. C., Steegers-Theunissen, R. P., de Vries, J. H., Laven, J. S., \& Koster, M. P. (2017). Strong adherence to a healthy dietary pattern is associated with better semen quality, especially in men with poor semen quality. Fertility and Sterility, 107(4), 916-923. e912.

Oyeyipo, I. P., Raji, Y., Emikpe, B. O., \& Bolarinwa, A. F. (2011). Effects of nicotine on sperm characteristics and fertility profile in adult male rats: A possible role of cessation. Journal of Reproduction \& Infertility, 12(3), 201.

Pajarinen, J., \& Karhunen, P. (1994). Spermatogenic arrest and 'Sertoli cell-only'syndrome-Common alcohol-induced disorders of the human testis. International Journal of Andrology, 17(6), 292-299.

Palani, A., Sengupta, P., Agarwal, A., \& Henkel, R. (2020). Geographical differences in semen characteristics: Comparing semen parameters of infertile men of the United States and Iraq. Andrologia, 52(3), e13519.

Palmer, N. O., Bakos, H. W., Fullston, T., \& Lane, M. (2012). Impact of obesity on male fertility, sperm function and molecular composition. Spermatogenesis, 2(4), 253-263.
Park, M., Choi, Y., Choi, H., Yim, J.-Y., \& Roh, J. (2015). High doses of caffeine during the peripubertal period in the rat impair the growth and function of the testis. International Journal of Endocrinology, 2015, 1-9. https://doi.org/10.1155/2015/368475

Penzias, A., Bendikson, K., Butts, S., Coutifaris, C., Falcone, T., Gitlin, S. ... Vernon, M. (2018). Smoking and infertility: A committee opinion. Fertility and Sterility, 110(4), 611-618.

Pook, M., Tuschen-Caffier, B., Kubek, J., Schill, W. B., \& Krause, W. (2005). Personality, coping and sperm count. Andrologia, 37(1), 29-35.

Rahimipour, M., Talebi, A. R., Anvari, M., Sarcheshmeh, A. A., \& Omidi, M. (2013). Effects of different doses of ethanol on sperm parameters, chromatin structure and apoptosis in adult mice. European Journal of Obstetrics \& Gynecology and Reproductive Biology, 170(2), 423-428.

Ramlau-Hansen, C., Thulstrup, A. M., Bonde, J. P., Olsen, J., \& Bech, B. (2008). Semen quality according to prenatal coffee and present caffeine exposure: Two decades of follow-up of a pregnancy cohort. Human Reproduction, 23(12), 2799-2805.

Ricci, E., Viganò, P., Cipriani, S., Somigliana, E., Chiaffarino, F., Bulfoni, A., \& Parazzini, F. (2017). Coffee and caffeine intake and male infertility: A systematic review. Nutrition Journal, 16(1), 37.

Sabanegh, E. J., \& Agarwal, A. (2012). Male infertility. In M. F. Campbell, P. C. Walsh, \& A. J. Wein (Eds.), Campbell-Walsh Urology (pp. 616647). Philadelphia, PA: Elsevier.

Salas-Huetos, A., Bulló, M., \& Salas-Salvadó, J. (2017). Dietary patterns, foods and nutrients in male fertility parameters and fecundability: A systematic review of observational studies. Human Reproduction Update, 23(4), 371-389.

Sansone, A., Di Dato, C., de Angelis, C., Menafra, D., Pozza, C., Pivonello, R., ... Gianfrilli, D. (2018). Smoke, alcohol and drug addiction and male fertility. Reproductive Biology and Endocrinology, 16(1), 3.

Schmid, T. E., Eskenazi, B., Baumgartner, A., Marchetti, F., Young, S., Weldon, R., ... Wyrobek, A. J. (2006). The effects of male age on sperm DNA damage in healthy non-smokers. Human Reproduction, 22(1), 180-187.

Sengupta, P. (2015). Reviewing reports of semen volume and male aging of last 33 years: From 1980 through 2013. Asian Pacific Journal of Reproduction, 4(3), 242-246.

Sengupta, P., Dutta, S., \& Krajewska-Kulak, E. (2017). The disappearing sperms: Analysis of reports published between 1980 and 2015. American Journal of Men's Health, 11(4), 1279-1304.

Sengupta, P., Dutta, S., Tusimin, M. B., İrez, T., \& Krajewska-Kulak, E. (2018). Sperm counts in Asian men: Reviewing the trend of past 50 years. Asian Pacific Journal of Reproduction, 7(2), 87-92.

Sermondade, N., Elloumi, H., Berthaut, I., Mathieu, E., Delarouzière, V., Ravel, C., \& Mandelbaum, J. (2010). Progressive alcohol-induced sperm alterations leading to spermatogenic arrest, which was reversed after alcohol withdrawal. Reproductive Biomedicine Online, 20(3), 324-327.

Sermondade, N., Faure, C., Fezeu, L., Shayeb, A. G., Bonde, J. P., Jensen, T. K., ... Czernichow, S. (2012). BMI in relation to sperm count: An updated systematic review and collaborative meta-analysis. Human Reproduction Update, 19(3), 221-231.

Sharma, R., Biedenharn, K. R., Fedor, J. M., \& Agarwal, A. (2013). Lifestyle factors and reproductive health: Taking control of your fertility. Reproductive Biology and Endocrinology, 11(1), 66

Sharma, R., Harlev, A., Agarwal, A., \& Esteves, S. C. (2016). Cigarette smoking and semen quality: A new meta-analysis examining the effect of the $\mathbf{2 0 1 0}$ World Health Organization laboratory methods for the examination of human semen. European Urology, 70(4), 635-645.

Siddeek, B., Mauduit, C., Simeoni, U., \& Benahmed, M. (2018). Sperm epigenome as a marker of environmental exposure and lifestyle, at the origin of diseases inheritance. Mutation Research/Reviews in Mutation Research, 778, 38-44.

Skakkebæk, N.-E., Meyts, R.-D., \& Main, K. (2001). Testicular dysgenesis syndrome: An increasingly common developmental disorder with environmental aspects: Opinion. Human Reproduction, 16(5), 972-978. 
Soelberg, C. D., Brown, R. E., Du Vivier, D., Meyer, J. E., \& Ramachandran, B. K. (2017). The US opioid crisis: Current federal and state legal issues. Anesthesia \& Analgesia, 125(5), 1675-1681.

Soubry, A. (2015). Epigenetic inheritance and evolution: A paternal perspective on dietary influences. Progress in Biophysics and Molecular Biology, 118(1-2), 79-85.

Swan, S. H., Elkin, E. P., \& Fenster, L. (2000). The question of declining sperm density revisited: An analysis of 101 studies published 19341996. Environmental Health Perspectives, 108(10), 961-966.

Viganò, P., Chiaffarino, F., Bonzi, V., Salonia, A., Ricci, E., Papaleo, E., ... Parazzini, F. (2017). Sleep disturbances and semen quality in an Italian cross sectional study. Basic and Clinical Andrology, 27(1), 16.

Vujkovic, M., de Vries, J. H., Dohle, G. R., Bonsel, G. J., Lindemans, J., Macklon, N. S., ... Steegers-Theunissen, R. (2009). Associations between dietary patterns and semen quality in men undergoing IVF/ ICSI treatment. Human Reproduction, 24(6), 1304-1312.

Wagenmaker, E. R., Breen, K. M., Oakley, A. E., Tilbrook, A. J., \& Karsch, F. J. (2009). Psychosocial stress inhibits amplitude of gonadotropin-releasing hormone pulses independent of cortisol action on the type II glucocorticoid receptor. Endocrinology, 150(2), 762-769.

Wallach, E. E., Kandeel, F. R., \& Swerdloff, R. S. (1988). Role of temperature in regulation of spermatogenesis and the use of heating as a method for contraception. Fertility and Sterility, 49(1), 1-23.

WHO (2010). Examination and processing of human semen. WHO laboratory manual for the examination and processing of human semen, 5th ed. Geneva, Switzerland: World Health Organization.
Yang, X.-Y., Gu, Y.-J., An, T., Liu, J.-X., Pan, Y.-Y., Mo, F.-F., ... Jiang, G.J. (2018). Proteomics analysis of testis of rats fed a high-fat diet. Cellular Physiology and Biochemistry, 47(1), 378-389.

Yao, D. F., \& Mills, J. N. (2016). Male infertility: Lifestyle factors and holistic, complementary, and alternative therapies. Asian Journal of Andrology, 18(3), 410.

Yildirim, O. G., Sumlu, E., Aslan, E., Koca, H. B., Pektas, M. B., Sadi, G., \& Akar, F. (2019). High-fructose in drinking water initiates activation of inflammatory cytokines and testicular degeneration in rat. Toxicology Mechanisms and Methods, 29(3), 224-232.

Zalata, A. A., Ahmed, A. H., Allamaneni, S., Comhaire, F. H., \& Agarwal, A. (2004). Relationship between acrosin activity of human spermatozoa and oxidative stress. Asian Journal of Andrology, 6(4), 313-318.

Zorn, B., Auger, J., Velikonja, V., Kolbezen, M., \& Meden-Vrtovec, H. (2008). Psychological factors in male partners of infertile couples: Relationship with semen quality and early miscarriage. International Journal of Andrology, 31(6), 557-564.

How to cite this article: Leisegang K, Dutta S. Do lifestyle practices impede male fertility?. Andrologia. 2020;00:e13595. https://doi.org/10.1111/and.13595 